\title{
THE STRUCTURE OF PERICLINAL CHIMERAS
}

\author{
R. A. E. TILNEY-BASSETT \\ Botony School, Oxford
}

Received 20.xii.62

\section{THE ANALYSIS OF PERICLINAL CHIMERAS}

(a) Hypotheses and assumptions

(i) The Graft-hybrid hypothesis. Gardeners had been puzzled, since the beginning of the nineteenth century, by the frequent bud variations arising on Citrus-The Bizzaria Orange, Laburnum adami and later, Crataegomespilus. Certain observations were made:

(I) All these trees showed characters intermediate between those of other well known types; this led to the belief that they were hybrids.

(2) The bud variations from these plants had characters closely resembling the types that were thought to be their parents; this supported the hybrid concept.

(3) In all cases the trees were propagated by grafting.

These observations led to the Graft-hybrid hypothesis which was known by Darwin (1875) but which probably originated earlier in the discussions of unknown gardeners. The hypothesis assumed that fusion took place between vegetative nuclei of stock and scion resulting in the production of a homogeneous hybrid growing point. Bud variations were thought to be a consequence of somatic segregation analogous to the segregation of different seedling characters from sexual hybrids.

The hypothesis raised a problem of fundamental importance since the fusion of vegatative cells was in marked contrast to the normal formation of hybrids by the fusion of sexual cells. Experimental evidence was needed with which to confirm or reject the hypothesis.

(ii) The Chimera or layer hypothesis. In order to test the Graft-hybrid hypothesis, Winkler (1907) made grafts between two species of Solanum, $S$. lycopersicum and $S$. nigrum. He produced from callus buds a number of plants which he believed to be real graft hybrids. But one graft resulted in a plant, which he recognised as not being a hybrid, in which the shoot was divided into two halves; one half was composed of one parent $S$. nigrum and the other half of $S$. lycopersicum, the second parent. This plant which was composed of tissues of two genetically distinct types, he termed a Chimera.

The next step resulted from the following observations on the structure and breeding behaviour of white-margined Pelargonium varieties made by Baur (1909):

(I) Leaf sections revealed that the cells of the palisade mesophyll, R 2 
next to the upper epidermis, and the cells of the spongy mesophyll, next to the lower epidermis, were colourless.

(2) Normal green leaves had no outer colourless cells; conversely white leaves had no green cells.

(3) On selfing only white seedlings were produced.

(4) Occasionally pure white shoots or pure green shoots arose on these varieties which, on selfing, produced only white or green seedlings respectively.

(5) On crossing green and white-margined varieties, green, variegated and white seedlings were obtained.

The foundation for understanding these plants was the analysis of the fundamental structure of the shoot apex by the anatomists of the late nineteenth century. They found that the growing-point was frequently constructed of two or three germ layers which were superimposed one above the other like a series of cones from which the body structure of the plant was derived. Thus Baur explained the chimeral patterns met with in Pelargonium leaves by assuming that the growing-points themselves were composite, i.e. the pattern found in the leaf was a development of the pattern already present at the growing-point. Bud variations were therefore alterations in the ordered arrangement of the germ layers. For convenience in description the germ layers, of which only the inner can be more than one cell thick, have been termed L I, L II and L III (Satina and Blakeslee, I94I) from the ouside to the inside. If a plant has a 2-layered apex L III is missing.

Among the variegated seedlings there were plants in which onehalf of the axis had green leaves and the other half white leaves. Leaves which were half green, half white were occasionally produced on the border of the two halves of the axis. Baur concluded ( $p .342$ ) that:

"These plants have, therefore, quite evidently a sectorially divided growing point just as in the well known chimeras of Winkler."

These plants Baur called Sectorial Chimeras.

Other variegated seedlings developed leaves with white margins and green centres similar to the parental white-margined varieties; these confirmed Baur's second conclusion:

"With that is indeed the nature of white-margined plants clear, they are likewise chimeras, not chimeras with sectorially divided growing point but chimeras with periclinally divided growing point, in short they may be called Periclinal Chimeras."

Shortly afterwards Winkler (I9IO) admitted that some, but not all, of his so-called graft hybrids of Solanum were in fact periclinal chimeras. At the same time one of the classic graft-hybrids, Laburnum adami, was shown by Buder (I910) to be a periclinal chimera with a single layer of Cytisus purpureus, forming the epidermis, over a two-layered core of Laburnum vulgare. This confirmed Winkler's 
interpretation (1910) of the earlier work of Macfarlane (1895, p. 268) from which he and Buder (1910) drew attention to the following:

"But the very striking resemblance which the epidermis of the hybrid portion has to that of $C$. purpureus, not only in the general structure of the cells, but in the size and structure of the cell nucleus, the distribution of the stomata, and specially of hairs, would seem at first sight to prove that the hybrid portion was wrapped round, so to speak, by an epidermis of C. purpureus."

Macfarlane, however, had been so much impressed by the traditional Graft-hybrid hypothesis, that he was unable to see that his own observations conflicted with it and made quite a different interpretation possible.

(iii) The false assumption: green or white epidermis? Baur assumed that if the subepidermis formed a white skin around the green core, in his white-margined Pelargoniums, then the epidermis must also be genetically white. In short, a white-over-green (W-o-G) chimera had two layers of white over one layer of green. This was the simplest assumption, which can sometimes be the case, but Baur had no evidence that it was so in his Pelargoniums, indeed we now know that it was not. But alas, this false assumption became a generalisation for most chimeras which was maintained for many years ahead in spite of a steady accumulation of observations to the contrary. These we may now examine.

\section{(b) Experiments and observations}

Following Baur's discovery of periclinal chimeras, the graft-hybrids were re-examined and all were shown to be chimeras. But many years elapsed before the structure of chlorophyll chimeras was fully analysed and the possible types of chimera became known.

(i) Root cuttings. The variety Bridesmaid of Bouvardia had pink flowers, but root cuttings from it were found by Bateson (Igi6) to have red flowers and to resemble another variety-Hogarth. Additional reports which have been listed by Jones (I934), had also been made by gardeners, of other plants, such as the Pelargoniums, in which root cuttings differed from shoot cuttings (plate I). Bateson realised that these observations were a proof of the periclinal structure of these plants and he came to the following conclusion (p. 76):

" Buds formed on true roots arise by endogenous growth from the central tissues which, pushing through the outer cortex, grow into plants exhibiting the characters proper to the core. Whenever, therefore plants grown from root cuttings differ from those grown from stem cuttings, we may infer that the plant is a periclinal chimera having the tissues of the core differing genotypically in one or more ways from the tissues of the skin."

(ii) Reversal. Two bud variations, frequently observed on W-o-G chimeras, were explained in terms of the shoot arising from cells either of the skin, to give a pure white shoot, or from the core, to give a pure green shoot. But a third variation puzzled Bateson. 
This was the observation, which he termed reversal (1919), that some W-o-G chimeras, such as Pelargonium zonale $(P . z$.) var. Madame Salleron, occasionally appeared to turn inside out by producing leaves with G-o-W constitution (plate II). (Baur recorded the same change in P.z. J. C. Mapping but without comment.) Bateson noticed that the pattern produced, when reversal occurred in one sector of the leaf, was not the same as the pattern produced when the green core broke through the white skin to the very edge of the leaf. However, he failed to appreciate the significance of this difference and was only able to suggest (I92I) that the W-o-G might be an arrangement mechanically less stable than G-o-W. More records of reversal have since been obtained (table 4 ) but as Bateson observed, never in the opposite direction.

(iii) Green-over-white chimeras $(G-0-W)$. The leaves of P.z. Freak of Nature (Plate II) were observed by Bateson (1919) to vary from those, which were almost all white, to others, which had large, green, irregular-shaped, marginal lobes leaving only a small white centre; Spirea (Filipendula) ulmaria variegata (Bateson, I92I) (plate II) and Hydrangea hortensis (H.h.) nivalis (Sabnis, I923) had similar leaves. These leaves were distinct from other G-o-W chimeras which had their white centres masked by a green skin.

The sterility of Freak of Nature prevented Chittenden (1926) from testing the character of L II by breeding. Pure green bud variations, however, and G-o-W bud variations in which the white centre was masked (plate II) were fertile, and gave only green seedlings. White bud variations, in which the leaves were occasionally flecked with green (plate II), gave two green seedlings as well as many white. Owing to the sterility of its pollen Chittenden was unable to self $H . h$. nivalis but when he crossed it with pollen from a green plant, only green offspring were obtained. Spirea ulmaria variegata was quite sterile.

The breeding experiments of Correns (1920) with white-margined Veronica gentianoides albocincta (plate III) had shown that the germ cells developed in the green layer. Chittenden (1927) argued that this meant that L II was green and therefore the white margin must have developed from L I. It is surprising, therefore, that he did not similarly consider that L II was green in $H . h$. nivalis from which he had obtained also only green seedlings. Instead he considered that the green margins of H.h. nivalis as well as Freak of Nature and Spirea ulmaria were comparable to the white margins of Veronica and were similarly derived from L I by periclinal and anticlinal divisions at the leaf margins. He was unwilling to commit himself because he could not confirm the colour of the epidermis by examination of the plastids in the guard cells. The white margin is also developed from L I in the Dicotyledons, Sambucus nigra albocincta (Renner, I936b) and Prunus pissardi var. Hessei (Renner and Voss, 1942).

It is probable that Chittenden examined the epidermis of Freak 
of Nature with a high-dry lens with which the plastids are too small to see their colour. I have made observations with the oil immersion lens $\left(X_{1500}\right)$ and found the plastids in the guard cells to be green. There are also a few small, green plastids in the epidermal cells.

(iv) White-over-green chimeras $(W-o-G)$. White shoots, bud variations from Madame Salleron, were observed by Küster (Igrg) to have occasional small green flecks on the margins. Kümmler agreed (1922), but added that more rarely white shoots were formed which never showed the flecking. The reverse situation, in which green leaves from a variegated seedling of Pelargonium had white flecks, was noticed by Noack (1922). White flecks on the margins of green bud variations from the chimeras P.z. Flower of Spring (plate I), and P.z. Caroline Schmidt were observed by Bateson (1924).

Two W-o-G varieties of H.h. variegata were described by Sabnis (1923). In one variety (plate II) green lobes, and in the second, yellow lobes, were frequently developed on the margin, especially in the teeth. The lobes were separated from the central green core by the white skin. Sabnis thought that the lobes were developed from occasional green cells in the white layer, but he did not suggest how these isolated cells were maintained in a stable chimera.

When these two Hydrangea chimeras were crossed with pollen from a green plant, Chittenden ( 1926 ) obtained green and white seedlings from the green lobed, and yellow and white seedlings from the yellow lobed variety, moreover the proportions appeared to vary with the degree of lobing of the leaves on the same branch. The reciprocal crosses gave only green seedlings. This unexpected relationship between the lobes and the seedlings produced was even more marked in P.z. Golden Brilliantissima, a W-o-G chimera with yellow lobes. In this case the few seedlings produced were all yellow, and white seedlings, expected from a typical W-o-G Pelargonium chimera (Baur, I 909), were absent. I think it possible that the absence of white seedlings might have been due to their very low viability.

Once again Chittenden (1927) was unable to determine the nature of the epidermis of these chimeras and consequently he did not attempt a final analysis of their structure.

\section{(c) The role of the epidermis}

(i) Monocotyledons. Funkia (Hosta) sieboldiana albomarginata (plate III) is a W-o-G chimera which Chodat (I9Ig) found to contain colourless plastids in the guard cells of the leaf epidermis both over the white margin and over the green centre. He also examined the G-o-W var. medio-variegata and found that the plastids were green both over the green margin and over the white centre. There was thus an exact correlation between the colour of the margin and the colour of the plastids in the guard cells. Therefore, Chodat concluded, the margin must be developed from the epidermis.

Breeding experiments supported Chodat's conclusion. Green 
offspring from the W-o-G Chlorophytum elatum albomarginatum and white offspring from the G-o-W var. medio-variegatum were obtained by Collins (1922) in all crosses in which the chimeras were used as the female parent. Similar results were obtained by Yasui (1929) from chimeras of Hosta japonica. The seedlings, which are assumed to be derived from L II, thus corresponded to the central leaf tissue. Hence the marginal leaf tissue must have been derived from L I. It was therefore, evident that these Monocotyledons had a 2-layered growing point in which the W-o-G chimera had the layer structure WG and the G-o-W the structure GW corresponding to L I II.

There are, however, other Monocotyledons, which have recently been discussed in detail by Clowes (1957), that do not have a simple 2-layered structure. Thus the striped-leaved varieties of Dracena have been shown by Renner and Voss (1942) and by Thielke (1948) to be 3-layered. The striped varieties of Commelina, Tradescantia and Zebrina have also been shown to be periclinal chimeras with a rather specialised development (Thielke, 1954). On the other hand the leaves of some grasses are developed entirely from L I (Thielke, I 95 I) and are, therefore, unable to form recognisable periclinal chimeras.

Unfortunately, and I think surprisingly, many years elapsed before Chodat's demonstration of the importance of the epidermis was applied in the structural analysis of Dicotyledons.

(ii) Dicotyledons. Green chloroplasts were observed in the guard cells of the white bud variations from Madame Salleron, which produced green flecks, by Kümmler (1922). The white shoots, which never produced green flecks, had colourless plastids. But unlike Chodat he failed to relate these observations. Altogether, green chloroplasts were found in the guard cells of eight W-o-G chimeras by Kümmler (1922) and Rischkow (1927). But it was not until I934 that Jones, who probably did not know these German papers, pointed out the importance of the epidermis in chlorophyll chimeras (p. Ioo) as follows:

"Since there is no appearance of a green skin over the central areas of the leaves and other white parts of the variety of Hydrangea under consideration (H.h. nivalis), it is reasonably certain that a green skin, if present, is not more than one cell layer thick, comprising, that is to say, the epidermis only. . . . the simplest way of accounting for the green leaf border is to assume that it is a product of periclinal divisions in the dermatogen or superficial layer of the apical meristem."

Jones accounts for the green seedlings obtained by Chittenden (1926) by making the further assumption that the placental region of the ovary, like the leaf margin, is formed from L I. But Renner ( $1936 a$ ) points out that if L II was white, owing to the action of a recessive gene, the $F_{1}$ seedlings resulting from Chittenden's cross would be heterozygous and, therefore, all green. These alternative possibilities have never been resolved.

The green margin of Freak of Nature (plate II) Jones believed 
to be also derived from $\mathrm{L}$ I. In this case the anatomical investigations of Renner (1936b) and Thielke (1948) clearly supported him. Furthermore, the two green seedlings obtained from the green-flecked, white shoots, by Chittenden (1926), supported Jones's hypothesis that seedlings can sometimes be derived from $\mathrm{L} \mathrm{I}$.

The anatomical investigations of Thielke (1948) showed that the green margin of Spiraa ulmaria variegata (plate II) was developed from the epidermis, which confirmed Jones's assumption that it had a structure similar to $H . h$. nivalis and P.z. Freak of Nature.

The structure of the W-o-G H.h. variegata (plate II) Jones explained (p. I03) as follows:

"In the variety variegata it is suggested that the growing point possesses a green core surrounded by a two-layered skin which is composed of an inner layer of colourless tissue and an outer layer of green tissue . . the existence of this type of structural arrangement of the growing point of a chimera has never been hypothesized, yet there is no reason why such a chimera structure should not be perfectly stable, nor is there any difficulty in picturing simple ways in which it could originate."

Furthermore (p. 103):

"In the variety now under discussion (H.h. variegata), it is suggested that similar periclinal divisions (as in $H . h$. nivalis) in the dermatogen occur, the activity of division varying locally in still greater degree, so that anything from a continuous green band of varying width to a series of disconnected green lobes may result."

The yellow lobed variety was similar and Jones compared it with P.z. Golden Brilliantissima (p. 105) as follows:

"Golden Brilliantissima thus appears as an exact parallel to that variety of Hydrangea hortensis with leaves having yellow lobes, and it is susceptible of similar interpretation."

The unexpected seedlings, corresponding to the yellow or green marginal lobes of these chimeras (Chittenden, 1926), Jones explains by assuming that there is a great activity in the dermatogen in the formation of the placenta. I should point out that this explanation does not imply that the placenta develops in an unusual position. On the contrary, it implies that the placenta initials which are usually derived from L II are frequently displaced as a result of periclinal divisions in LI. Consequently, if the placenta is to develop in its normal position, it must now develop from initial cells derived from $\mathrm{L} I$ and will, therefore, produce seedlings corresponding to $\mathrm{L} I$.

This major break-through was due to Jones's realisation that the epidermis played just as important and independent a part in the behaviour and development of 3-layered chimeras as the second and third layers. Thus the assumption that the epidermis in chlorophyll chimeras was always genetically the same as the subepidermal layer was finally, twenty-five years after Baur's paper, found to be false.

Independently of Jones, Imai $\left(1935^{b}\right)$ also came to the conclusion 
that certain W-o-G chimeras had only the second layer white. But in 1936 he rejected this hypothesis because it did not support his theory of the automutability of plastids. Renner ( $1936 a$ ) and Rischkow (1936) agreed with Jones.

Two types of white shoot, one with occasional green flecks (plate II), the other with no flecks, had been observed as bud variations from Freak of Nature (Chittenden, 1926) and Madame Salleron (Kümmler, 1922). Jones (1934) believed that flecking was due to isolated islands of green tissue scattered throughout the otherwise white growing point. Imai ( 1936$)$ considered that in green-ticked shoots the plastids were automutable to green but remained constant in non-ticked shoots. I believe that these explanations were wrong and that the correct interpretation for Madame Salleron was that given by Renner (1936a, p. 259) as follows:

"I conjecture, that here and in similarly behaving white-margined Pelargoniums it is a question of a mesochimera,* with potentially green epidermis, colourless subepidermis and green core. Thus the white shoots will often possess not only a phenotypically colourless tissue but external to this there will be a normal epidermis, and as soon as this produces mesophyll tissue, a green fleck will appear. It is to be remembered, that in Madame Salleron the reversal of white-over-green to green-over-white has often been observed, and that also this phenomenon may be best explained on the assumption of a mesochimera structure."

The explanation of reversal, given so briefly by Renner, has been fully developed by Dermen (1950).

Bateson (1924) had observed green shoots from white-margined Flower of Spring (plate I) and Caroline Schmidt developing white flecks and sometimes reconstituting a new white margin. These changes were also explained by Renner (1936a, p. 261) as follows:

"It is highly likely, that apparently pure green shoots were in reality white-over-green (white epidermis). Loss of one germ layer (from GWG mesochimera) would be more frequent than loss of two layers at once, and through division of the epidermis of the growing point would reconstitute the normal white-over-green type."

Hence a chimera, which in the first place has only the middle layer white, can change so as to have both the outer and middle layer white, and the plant will appear both before and after as a W-o-G chimera.

In my opinion, not one of the explanations so far given is correct for Freak of Nature. I have examined epidermal strips from the two types of white shoot. The leaves from the pure white shoots have colourless plastids in their guard cells, but the leaves from greenflecked, white shoots have green chloroplasts even when there are no flecks on the leaves examined. This means that the green flecks are not derived from isolated islands of green epidermis, as suggested by Jones and Renner, but from a wholly green epidermis. Thus the

* Mesochimera - a periclinal chimera in which only the middle layer is different (Winkler, 1935): ABA or BAB. 
difference between these green-flecked, white shoots and the variety is due to the loss of the unusual faculty of the epidermis to divide prolifically at the leaf margins. This loss is not unexpected since it also occurs in the bud variations to pure green and to the G-o-W chimera in which the white centre is masked. Indeed, as pointed out by Renner and Voss (1942) and by Thielke (1948), the epidermis. proliferates only in the clone in which two white layers lie beneath the green layer. Hence, the green-flecked, white shoots arise not from a structural rearrangement of the germ layers, as is the case with the pure white shoots, but from a developmental change in the behaviour of the epidermal initial cells of the leaf. In effect, the temporary superlayering of the epidermis in leaf formation reverts to the condition, normal for other Pelargonium varieties, of a single layer. Presumably this change could occur as the result of either a mutation or, more likely, a physiological change in a system controlling the developmental behaviour of L I and its derivative cells: but this is still an open question.

Rischkow (1936) found that in Petunia hybrida one W-o-G chimera produced marginal green flecks while another did not. He related these observations to the presence of a green epidermis in one plant and to a colourless epidermis in the other. He had thus, independently, come to the same conclusion as Renner (1936a) in his interpretation of some Pelargonium chimeras.

Four structural arrangements, which may be designated $A B B$, $\mathrm{BAA}, \mathrm{AAB}$ and $\mathrm{BBA}$ had been analysed from the graft chimeras of Solanum lycopersicum and $S$. nigrum by Winkler (IgIo). Four of the chlorophyll chimeras or their bud variations, analysed by Jones, Renner and Rischkow (table I) were analogous; the mesochimera ABA (GWG) was a new structure. It was Imai, however, who showed the connection between the two and between these and other chimeras, by illustrating, for the first time, all the possible structures of chimeras in plants with 3-layered growing-points.

The first diagram (Imai, I934) showed that with two genetic types there are six possible structural arrangements together with the two pure types, AAA and BBB. The sixth type, not yet mentioned, was the mesochimera BAB. I should point out that chimeras with three genetic types $\mathrm{ABC}$ also have only six structural arrangements. In his study on the mutable genes affecting flower colour in Pharbitis nil, Imai (1935a, pp. 7-8) also points out that:

"Theoretically, twenty-seven combinations of the three histogens, variegated, self-coloured, and ground-coloured, as illustrated, should be expected as sports in tri-histogenic plants."

These genetic combinations, not to be confused with structural arrangements, were illustrated in his second diagram which is equally valid for all chimeras in plants with 3 -layered apices.

The importance of Imai's consideration of 3-layered chimeras with three genetic types has recently been demonstrated by the 
investigations of Bergann and Bergann (1959). They have shown that P.z. Madame Salleron is really a trichimera, in which all three layers are different. The genetic type of L I is normal, green with long internodes, L II is white with long internodes and L III is green but with dwarf internodes. Historically, they have found that the plastid difference was the first mutation to arise which gave the variety P.z. Manglesii. The second, a gene mutation in L III, to dwarf internodes came later. A second trichimera has also been described by Bergann ( $196 \mathrm{r}$ ) in Euphorbia pulcherrima. The analysis of these trichimeras has been supported by a series of excellent diagrams

TABLE I

Examples of periclinal structure in chlorophyll chimeras

\begin{tabular}{|c|c|c|c|}
\hline Author & Chimera & Bud variation & Structure \\
\hline Jones (1934) & $\begin{array}{l}\text { P.z. Freak of Nature } \\
\text { Spiraa ulmaria } \\
\text { H.h. nivalis } \\
\text { H.h. variegata } \\
\text { P.z. Golden Brilliantissima }\end{array}$ & $\begin{array}{l}\ldots \\
\cdots \\
\cdots \\
\cdots \\
\cdots\end{array}$ & $\begin{array}{l}\text { GWW } \\
\text { GWW } \\
\text { GWW } \\
\text { GWG and } \\
\text { YWG } \\
\text { YWG }\end{array}$ \\
\hline Renner (1936) . & $\begin{array}{l}\text { P.z. Madame Salleron } \\
\text { P.z. Madame Salleron } \\
\text { P.z. Madame Salleron } \\
P . z . \text { Madame Salleron } \\
P . z . \text { Flower of Spring } \\
P . z . \text { Flower of Spring } \\
\text { P.z. Flower of Spring }\end{array}$ & $\begin{array}{l}\text { Reversal, G-o-W } \\
\text { White Shoot, green flecks } \\
\text { White shoot, no flecks } \\
\quad \ldots \\
\text { Green shoot, white flecks } \\
\text { W-o-G chimera, no flecks }\end{array}$ & $\begin{array}{l}\text { GWG } \\
\text { GGW } \\
\text { GWW } \\
\text { WWW } \\
\text { GWG } \\
\text { WGG } \\
\text { WWG }\end{array}$ \\
\hline Rischkow (1936) & $\begin{array}{l}\text { Petunia hybrida } \\
\text { Petunia hybrida }\end{array}$ & $\begin{array}{l}\text { W-o-G chimera, green flecks } \\
\text { W-o-G chimera, no flecks }\end{array}$ & $\begin{array}{l}\text { GWG } \\
\text { WWG }\end{array}$ \\
\hline
\end{tabular}

clearly explaining the structural types and the changes they give rise to. These studies thus provide a new opportunity for the understanding of chimeras. I presume that the yellow-lobed variety of $H . h$. variegata and also P.z. Golden Brilliantissima (YWG, table I) were also trichimeras in which each layer contained genetically different plastids. Whereas the trichimeras described by Bergann result from the combination of both a gene and a plastid difference.

(iii) Gymnosperms. Most Gymnosperms do not have a layered shoot apex and are thus unable to form periclinal chimeras. The genera Chamacyparis, Funiperus (plate IV) and Thuja in the family Cupressacex, however, have been shown by Hejnowicz (1956 and 1959) to be exceptional since they form $W-o-G$ periclinal chimeras. These chimeras have L I white and L II green; there is no L III. Normally L I produces only the epidermis of the leaves and shoots which therefore appear green. But frequently, owing to duplication of $\mathrm{L} I$ in the apex, pure white leaves and shoots are formed. On 
the other hand, I have never seen perforation of the white L I by the green L II. Hence non-chimerical green shoots are rarely, if ever, formed. The plants themselves have a shrubby habit and branch vigorously so that new green or white shoots are continually arising. Since the white shoots are not self-supporting all the longterm growth must arise by branches from green shoots. Hence the plant combines the frequent instability of the individual shoots with the great stability of the chimera as a whole and the overall result is a variegated plant of considerable ornamental value.

\section{CLASSIFICATION OF CHIMERAS}

(i) The problem to-day

A sectorial chimera, with a white sector affecting the shoot, was found in a wild plant of Melandrium album by Baur (I9I I). In cultivation, it developed into a stable W-o-G periclinal chimera. Breeding experiments showed that the origin of the white layer was by a spontaneous gene mutation and not, as in his W-o-G Pelargonium chimeras (Baur, I909), by a plastid mutation. The green offspring obtained from H.h. nivalis (Chittenden, 1926), were explained by Jones (1934) on the assumption that the placental region of the ovary had developed from L I. But as Renner (1936a) pointed out, Jones overlooked the possibility that the white layer originated by a gene mutation. These experiments lead to the question as to how important is it to know whether a chimera had arisen by gene or by plastid mutation.

In a number of genera, including Euonymus, Eleagnus, Pelargonium (plate III) and Sedum, structures have been proposed for G-o-W chimeras which, in the absence of breeding data, I cannot fully accept. These chimeras have a green margin, and a white core which is not masked by an overlying green skin. The lack of masking has been explained by Imai (I934 and 1935b) on the assumption that the white plastids in these forms seem to secrete a toxic substance which bleaches out the green colour of the overlying cells. This explanation would be reasonable if the white layer had arisen by gene mutation. But it would be quite extraordinary if it had arisen by plastid mutation since there is no evidence that mutant plastids ever produce toxic substances that are diffusible from one cell to another. I feel, therefore, that before Imai's explanation of the structure of these chimeras can be accepted, breeding experiments, as well as anatomical experiments, must be made.

Furthermore, I believe that when more chlorophyll chimeras have been bred we may be able to relate certain chimera structures with an origin by gene mutation as distinct from others with an origin by plastid mutation. In the following classification scheme, therefore, by making the distinction between gene- and plastid-differential chimeras, I hope to draw attention to the need for more breeding experiments in the analysis of chlorophyll chimeras. 


\section{(ii) A proposed scheme}

Chimeras form a heterogeneous group of plants which are classifiable in three ways according to the need, as follows:

I. Origin. Chimeras originate in the following ways:

(I) Spontaneous mutation.

(2) Induced mutation.

(3) Sorting-out from variegated seedlings.

(4) Grafting.

II. Structure. As already defined by Baur (1909) the two structural groups are:
(I) Sectorial.
(2) Periclinal.

The term mericlinal is also used when only a sector of a shoot is periclinal. The periclinal chimeras are 2 or 3 -layered with respectively two or six structural arrangements.

III. Behaviour. In addition to the above group, I propose to classify chimeras into four genetically distinct classes (table 2). The first two classes that I list below are already in common usage.

(I) Species chimeras or "Graft chimeras". These are made artificially by grafting together different species or genera. At the point of union a callus tissue develops from the stock and scion from which chimerical adventitious buds arise. They are recognised as chimeras by the general differences between the cells of the species concerned.

(2) Chromosomal chimeras. Chimeras, in which the layers differ in their chromosome number, are made artificially by treating the germ layers with colchicine. They sometime arise naturally. The commonest, and simplest type to recognise, has the changed layer or layers with double the number of chromosomes. Compared with the diploid cells, these tetraploids are detected by greater nuclear size, or twice the number of chromosomes, and an increase in cell size.

(3) Gene-differential chimeras. When somatic mutation of a gene to its recessive allele, or back-mutation to its dominant allele, occurs in one of the germ layers, it produces a chimera. These chimeras arise naturally, but may be induced by X-rays or other mutagenic agents. They are recognised by their visible effects.

(4) Plastid-differential chimeras. These chimeras arise either by spontaneous plastid mutation or by sorting-out of two kinds of plastid from a mixed egg or mixed zygote. They are recognised by the variation of the leaves and distinguished from similar gene-differential chimeras by their different mode of inheritance, which is non-mendelian.

All plastid- and some gene-differential chimeras affect the colour of the plastids. It is often convenient to group these together as chlorophyll chimeras. The trichimera P.z. Madame Salleron (table 2) 
is probably both a plastid and a gene-differential chimera although, since the plant is sterile, this assumption has not been proved by

TABLE 2

Examples of the four genetical classes of chimeras

\begin{tabular}{|c|c|c|}
\hline Author and class & Plant & Description \\
\hline $\begin{array}{l}\text { Species } \\
\text { Buder (1910) } \\
\text { Winkler (1910). }\end{array}$ & $\begin{array}{l}\text { Laburnum adami } \\
\text { Solanum spp. }\end{array}$ & $\begin{array}{l}\text { Chimera between Cytisus purpureus } \\
\text { and Laburnum vulgare } \\
\text { Chimeras between different species }\end{array}$ \\
\hline $\begin{array}{l}\text { Chromosomal } \\
\text { Dermen (1960) } \\
\text { Avery, Satina } \\
\text { Rietsema (1959) }\end{array}$ & $\begin{array}{l}\text { Peach, Apple } \\
\text { Datura }\end{array}$ & $\begin{array}{l}2 x / 4^{x} \text { chimeras in various combina- } \\
\text { tions } \\
2 x / 4^{x / 8 x} \text { as sell as } 2 x / 4^{x} \text { chimeras }\end{array}$ \\
\hline $\begin{array}{l}\text { Gene-differential } \\
\text { Bateson (19r6) } \\
\text { Asseyeva (1927) } \\
\text { Darrow (1928). } \\
\text { Imai (1935a) } \\
\text { Dahlgren (1953) } \\
\text { Present obs. }\end{array}$ & $\begin{array}{l}\text { Bouvardia var. Brides- } \\
\text { maid } \\
\text { Potato tubers } \\
\text { Blackberry } \\
\text { Rhododendron obtusum } \\
\text { Fragaria vesca } \\
\text { P.z. Crystal Palace Gem } \\
\text { P.z. A Happy Thought }\end{array}$ & $\begin{array}{l}\text { Pink flowers, root cuttings gave } \\
\text { red flowers } \\
\text { Chimerical varieties } \\
\text { Thornless variety is a chimera } \\
\text { Mutable genes affecting flower } \\
\text { colour } \\
\text { Flowers with very small petals } \\
\text { Variegated leaf, golden-over-green } \\
\text { Variegated leaf, green-over-pale } \\
\text { green }\end{array}$ \\
\hline $\begin{array}{l}\text { Plastid-differential } \\
\text { Baur (19o9) } \\
\text { Present obs. }:\end{array}$ & $\begin{array}{l}\text { P.z. J. C. Mapping * } \\
\text { P.z. Flower of Spring }\end{array}$ & $\begin{array}{l}\text { W-o-G chimera } \\
\text { W-o-G chimera }\end{array}$ \\
\hline $\begin{array}{l}\text { Gene- and Plastid-differential } \\
\text { Bergann and Bergann } \\
(1959)\end{array}$ & P.z. Madame Salleron & $\begin{array}{l}\text { W-o-G chimera with dwarf inter- } \\
\text { nodes and no flowers }\end{array}$ \\
\hline
\end{tabular}

* Baur's description suggests that this plant is also a chimera for flower colour.

breeding. Nevertheless only the plastid difference can be described as a chlorophyll chimera.

\section{SURVEY OF CHLOROPHYLL CHIMERAS}

\section{(a) Introduction and methods}

There have been frequent studies of individual chlorophyll chimeras but few of the group as a whole. I have, therefore, begun a survey of the chlorophyll chimeras in the Oxford Botanic Garden.

It is frequently impossible to tell by appearance alone whether a chimera is 2 - or 3 -layered, and if 3-layered, which layers are normal and which mutant. Therefore, where practical, the following methods 
are used. These are described in the historical analysis and named after the worker who first used and interpreted them correctly:

(I) Baur's Test: Results of selfing. (L II).

(2) Bateson's Test: Root cuttings. (L II or L III).

(3) Chodat's Test: Examination of epidermis. (L I).

(4) Renner's Test: Bud variations. (L I, L II and L III).

(b) The structural analysis

(i) Spiræa japonica bumalda: a stable, unstable periclinal. The normal shoot of Spirea japonica bumalda is green, but it frequently produces pure white, as well as green, side shoots, and sometimes its own growing-point becomes white (plate IV). Furthermore, transitional stages are frequently produced in which the leaves have marginal, white sectors and even completely white margins. The growing-point of such a branch, however, soon becomes pure white, and its side shoots are invariably white. The white shoots are not hardy and each year new ones arise from the hardy green shoots. The flowers are quite sterile.

Serial sections through shoot apices were cut by Renner (1936b) to find evidence of periclinal divisions in L I, but his observations were negative. He therefore remained undecided between the alternative possibilities of a chimerical structure or frequent mutation.

In January $196 \mathrm{I}$, I took ten root cuttings which I placed in a mixture of sand and peat in the mist unit. The four successful cuttings were planted out in April and have since produced numerous green shoots with no sign of variegation, thereby confirming the chimerical structure of their parent. Furthermore, I have found colourless plastids in the guard cells of green leaves from the parent but green plastids in the guard cells of the root-cutting plants. This again confirms the chimerical structure and demonstrates that L I is white in the variegated plant.

The interest of Spirea lies in the similarity of its behaviour with the Gymnosperm chimeras (plate IV). Normally the white L I produces only the epidermis of the leaves which therefore appear green. But frequently, owing to duplication of $\mathrm{L} I$ in the apex, pure white shoots are formed. Occasionally bud variations produce an intermediate stage of short duration in which the leaves have a wide white margin; evidently the normal structure of Spirea, like the Gymnosperms, is WG but temporarily it may appear to be WWG. Again I have never seen perforation of the white L I by the green L II, except from my root cuttings. Hence we have in Spirea japonica bumalda the first example of a Dicotyledon which, like the Gymnosperms, combines the frequent instability of the individual shoots with the stability of the chimera as a whole.

Salvia officinalis variegata, in which the green leaves are frequently flecked with white and in which white shoots are not infrequent, may be similar to Spirea. My attempts to obtain new plants from 
root-cuttings have been unsuccessful, however, so that I have not yet been able to confirm my belief that it is another chimera with a white L I and green L II.

(ii) Origin, structure and behaviour of mesochimeras. The expected relationship between the six structural arrangements of 3-layered chimeras and their bud variations, as shown in table 3 , is based on the assumption that in each variation periclinal divisions in the cells of one layer, causing duplication of that layer, lead to displacement of the cells in the adjoining layer. This displacement is either a shifting of one layer further inward, or else an outer layer is perforated by the

TABLE 3

Relationship between the six chlorophyll chimeras having a 3-layered apex and their possible bud variations

\begin{tabular}{|c|c|c|c|c|c|c|}
\hline \multirow{2}{*}{$\begin{array}{c}\text { Initial } \\
\text { Constitution }\end{array}$} & \multicolumn{5}{|c|}{ Possibility of bud variations } \\
\cline { 2 - 7 } & GGG & WGG & WWW & GWW & GGW & WWG \\
\hline GGW & - & & & & & \\
\hline GWG & $\mathrm{X}$ & $\mathrm{O}$ & $\mathrm{X}$ & $\mathrm{X}$ & $\mathrm{X}_{1}$ & $\mathrm{O}$ \\
WGG & $\mathrm{X}$ & $\mathrm{X}$ & $\mathrm{X}$ & $\mathrm{X}$ & $\mathrm{X}^{*}$ & $\mathrm{X}$ \\
WWG & $\mathrm{X}$ & $\mathrm{X}$ & $\mathrm{X}$ & $\mathrm{O}$ & $\mathrm{O}$ & $\mathrm{X}$ \\
WGW & $\mathrm{X}$ & $\mathrm{X}$ & $\mathrm{X}$ & $\mathrm{O}$ & $\mathrm{O}$ & $\mathrm{X}_{1}$ \\
GWW & $\mathrm{X}$ & $\mathrm{O}$ & $\mathrm{X}$ & $\mathrm{X}_{1}$ & $\mathrm{X}$ & $\mathrm{X}^{*}$ \\
\hline
\end{tabular}

$\mathrm{X}=$ Bud variation possible ;

$\mathrm{X}_{1}=$ No change ;

$\mathrm{O}=$ Bud variation impossible ;

$\mathrm{X}^{*}=$ Reversal of phenotype.

duplicating layer. I do not believe that bud variations can ever occur by a direct reciprocal interchange of layers. As indicated by Renner (1936a), the phenomenon of reversal, in which the W-o-G chimera appears to turn inside-out to produce a G-o-W chimera, does not occur in this manner but as the result of the duplication of $\mathrm{L} I$ in GWG mesochimeras.

Of the six structural types of chimera (table 3) I have been mainly concerned with the two mesochimeras, GWG and WGW. I find that these two constitutions are of particular significance since they cannot be formed by the alteration of layers, either of each other, or of any of the four other structures; but by their layer alterations they can produce the remaining four. Thus they can have arisen only by mutation, or in the case of plastid-differential chimeras, by sorting-out from mixed egg cells, or mixed zygotes. The other four structures can originate either similarly or by layer alterations from three different existing chimeras in each dase. In table 4 , I give a iist of my own observations of W-o-G chimeras having a genctically green cpidermis, GWG. In each case I have detected green or sometimes pale green chloroplasts in the guard cclls, and frequently in all epidermal cells, by examination of their epidermal strips ( $X$ I 500$)$. 
The bud variations from the GWG mesochimeras (table 4) suggest that the most frequent change is simply a displacement of L III by duplication of L II (GWG to GWW). Similarly the duplication or triplication of L I frequently leads to the displacement of L II and

TABLE $_{4}$

Observations of marginal lobes or flecks in GWG mesochimeras and their bud variations

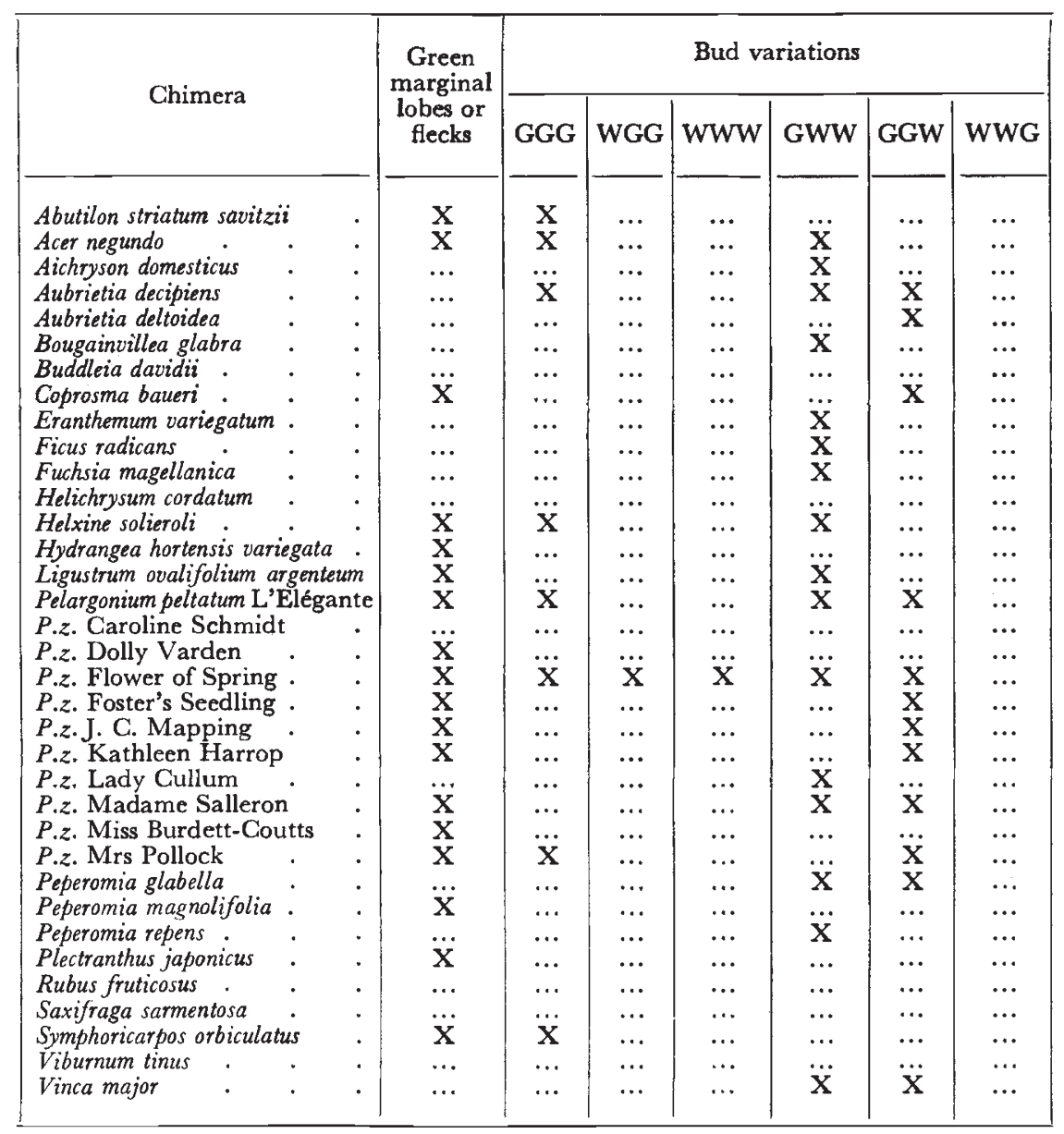

L III (GWG to GGW and GGW to GGG). Only in P.z. Flower of Spring has L I been perforated (GWG to WGG). These results suggest that green shoots from GWG chimeras, except those developed on roots, normally come from L I and not, as has always been suggested, from the core L III.

It is interesting to note that chimeras such as P.z. Dolly Varden in which the leaves frequently possess marginal lobes or flecks have, under my observation, never produced a reversal or green shoots. 
Thus L I which does not divide periclinally in the apex may do so frequently during leaf development. Conversely in the chimeras Aubrietia decipiens and Vinca major green shoots or reversal have been observed but I have never seen marginal flecks. Thus in this case L I appears to be less stable in the apex than during leaf development.

I have made reciprocal crosses between normal green plants and the Pelargonium varieties Dolly Varden, Flower of Spring, J. C. Mapping, Miss Burdett-Coutts and Mrs Pollock. In each case the inheritance has been non-mendelian and, owing to biparental inheritance of plastids in Pelargonium, I have obtained various proportions of green, variegated and white seedlings. These chimeras have, therefore, a plastiddifferential. In natural seed from Ligustrum ovalifolium argenteum I obtained 4 white and 16 variegated seedlings, a result which is best explained on the basis of biparental inheritance of two types of plastid. The reciprocal crosses between H.h. variegata and a green plant (Chittenden, 1926) demonstrated purely maternal inheritance of the mutant plastids so that this plant has a plastid-differential too. In a cross with a normal green plant, the male sterile $P$. $z$. Kathleen Harrop, when used as female parent, gave 63 green seedlings but no white or variegated. This result suggests that the plant is a genedifferential chimera. But I cannot be certain until I have the results of the $F_{2}$ generation in which $I$ would expect to see segregation into green and white offspring. I have made no breeding experiments with the other chimeras listed in table 4 .

The large number of chimeras in cultivation to-day is a tribute to the vigilance of gardeners by whom they have been found and propagated, partly because of their interest as rare sports, and partly because of their ornamental value. The high frequency of GWG mesochimeras, of which the list in table 4 is probably only a small sample, is, I believe, dependent upon the way in which each layer contributes to the development of the leaves in many Dicotyledons.

In most 3-layered chimeras, apart from occasional flecks and such exceptional plants as P.Z. Freak of Nature, L I produces only the epidermis of the leaf; it rarely produces a white margin such as described in Daphne odora by Imai (1935b). Consequently, mutations in L I will rarely produce a plant of any value to a gardener and will usually pass unnoticed. Mutations in L III are frequently masked by the green L II; it is only when they are not masked that an ornamental plant such as P.z. A Happy Thought is produced. Furthermore, L III is the least stable layer so that this type of chimera easily reverts to normal. Mutations in L II, on the other hand, invariably produce a chimera in which the leaves have a conspicuous white margin at once recognisable for its ornamental value. Chimeras with both L I and L II white, such as I have found in P.z. Chelsea Gem, are less common because there must either be a mutation in two layers, which is unlikely, or they must be derived from WGG or GWG chimeras by secondary changes (table 3). In Pelargonium, 
owing to the biparental inheritance of the plastids, many chimeras have arisen as the result of breeding followed by the sorting-out of plastids from variegated seedlings; these could give rise to the WWG chimera structure directly. Few genera have more than one W-o-G chimera variety, however, so it is reasonable to suppose that the majority have arisen by mutation.

I have found no record either in the literature or from my own observations of the second mesochimera, WGW. I presume that the unlikelihood of a double mutation in L I and L III is the cause of its absence.

\section{SUMMARY}

I. The structural analysis of chimeras began in the nineteenth century with observations on the variability of the branches in certain trees. These were explained by the erroneous Graft-hybrid hypothesis which has been superseded by the Chimera or layer hypothesis put forward in 1909 .

2. Chimeras were shown to be either sectorial or periclinal but, owing to failure to recognise the importance of the unseen epidermis, it was not until the r93os that the full range of the 3-layered periclinal structures was understood. These have six structural arrangements-GGW, GWG, WGG, WWG, WGW and GWW. The highly variable modes of development of the two or three germ layers, in the formation of the body layers of the leaf, are responsible for the different structural appearances.

3. The importance of breeding experiments in the analysis of periclinal chimeras has too often been overlooked. Without breeding data, I cannot fully accept the "bleaching" explanation that has been given for the structure of some unmasked G-o-W chimeras, since it appears to rely on the unproven assumption that the mutant layer has arisen by gene rather than by plastid mutation.

4. Classification of periclinal chimeras may be by their origin, structure or behaviour. I propose to classify them by behaviour into four genetically distinct groups as follows:

(i) Species chimeras or "Graft chimeras".

(ii) Chromosomal chimeras.

(iii) Gene-differential chimeras.

(iv) Plastid-differential chimeras.

5. Chlorophyll chimeras have either a gene- or a plastid-differential and are distinguished by breeding. They are produced by spontaneous or induced mutation of genes or plastids in the growing point followed by sorting-out; occasionally new plastid-differential chimeras arise from the progeny of a variegated ancestor by sorting-out from mixed eggs or zygotes.

6. Spirea japonica bumalda is shown to be a chimera in which layer I is white and layer II green. It is the first record of a Dicotyledon 
behaving in a similar manner to the Gymnosperms-Chamacyparis, Funiperus and Thuja. These plants combine the frequent instability of individual shoots, owing to duplication of L I, with the great stability of the chimera as a whole, owing to failure of L II to perforate $\mathrm{L} \mathrm{I}$ and to the long-term inviability of all bud variations.

7. The relationship between the structure of 3-layered chimeras and their possible bud variations is shown in table 3. My observations suggest that chimeras of the type GWG, termed mesochimeras, are very common but the reciprocal, WGW, is unknown in cultivation.

8. The possible bud variations from GWG mesochimeras have all been observed in Pelargonium zonale var. Flower of Spring (5 of the 6 by myself). Displacement of inner layers by duplication or triplication of L I (GWG to GGW and GGW to GGG) or of L II (GWG to $G W W$ ) is common; but perforation of an outer layer by an inner layer (GWG to WGG) is rare. I believe, therefore, that green bud variations from mesochimeras normally come from $\mathrm{L} I$ and not, as has usually been assumed, from the core L III; shoots developed on roots are an exception.

9. The mesochimeras observed differ widely in the stability of L I. This can be stable both in the apex and in leaf development, or it can be unstable in both, or it can be stable in one position, or at one time in development, but unstable in another.

Acknowledgments.-I am extremely grateful to Professor C. D. Darlington for his encouragement, advice and invaluable suggestions in preparing the manuscript.

I would also like to thank the Christopher Welch Trustees for a Scholarship which has enabled me to prepare this article while studying for a D.Phil. degree in the University of Oxford.

\section{REFERENCES}

ASSEYEVA, T. 1927. Bud variations in the potato and their chimerical nature. 7. Genet., $19,1-26$.

AVery, A. G., SAtina, s. And Rietsema, J. 1959. Blakeskee: The Genus Datura. The Ronald Press Company, New York.

Bateson, w. ig16. Root cuttings, chimæras and sports. I. 7. Genet., 6, 75-80.

Bateson, w. i919. Studies in variegation. I. 7. Genet., 8, 93-99.

BAteson, w. i 921 . Root cuttings and chimæras. II. f. Genet., iI, 93-97.

BAteson, w. 1924. Note on the nature of plant chimæras. Studia Mendeliana. Brün. 9-12.

BAUR, E. I 909 . Das Wesen und die Erblichkeitsverhältnisse der "Varietates albomarginatac hort" von Pelargonium zonale. Z. Vererbungslehre, I, 330-35I.

BAUR, E. 1911. Untersuchungen über die Vererbung von Chromatophorenmerkmalen bei Melandrium, Antirthinum und Aquilegia. Z. Vererbungslehre, 4, 8I-IO2.

BERGANN, F., AND BERGANN, L. 1959. Über experimentell ausgelöste vegetative Spaltungen und Umlagerungen an chimärischen Klonen, zugleich als Beispiele erfolgreicher Staudenauslese. I. Pelargonium zonale: Madame Salleron. Zuchter, 29, 361-374.

BERGANN, F. 196I. Eine weitere Trichimäre bei Euphorbia pulcherrima. Biol. Zbl., $80,403-412$.

BUder, J. rgio. Studien an Laburnum adami. I. Die Verteiling der Farbstoffe in den Blutenblättern. Ber. disch. bot. Ges., 28, 188-192. 
Chittenden, R. J. 1926. Studies in variegation. II. Hydrangea and Pelargonium with notes on certain chimerical arrangements which involve sterility. $\mathcal{J}$. Genet., $16,43-61$.

CHITtENDEN, R. J. 1927. Vegetative segregation. Bibliogr. genet., 3, 355-439.

chodat, R. 1919. La Panachure et les Chimères dans le Genre Funkia. C.R. Soc. Phys. Hist. nat. Geneve, $36,8 \mathrm{I}-85$.

CLOWES, F. A. L. 1957. Chimeras and Meristems. Heredity, II, 141-148.

COLLINS, E. J. 1922. Variegation and its inheritance in Chlorophytum elatum and Chlorophytum comosum. 7. Genet., 12, 1-17.

CORRENS, C. 1920. Vererbungsversuche mit buntblättrigen Sippen. III. Veronica gentianoides albocincta. IV. Die albomarmorata- und albopulverea-Sippen. V. Mercurialis annua versicolor und xantha. S.B. preuss. Akad. Wiss., 212-240.

DAHLGREN, K. v. o. 1953. Die Eigenartigen Vererbungsverhältnisse der Micranthaform von Fragaria vesca. Svensk bot. Tidskr., 47, 1-1 5 .

DARrow, G. M. 1928. Notes on thornless blackberries. F. Hered., r9, 139-142.

DARWIn, C. 1875. Animals and Plants under Domestication. 2nd ed. John Murray, London.

DERMEN, H. 1950. Pattern reversal in variegated plants. J. Hered., 4r, 325-328.

Dermen, H. 1960. Nature of plant sports. The American Horticultural Magazine, 123-1 73 .

HejNowicz, z. 1956. The first periclinal chimera among Gymnosperms. Acta Soc. Bot. Polon., 25, 181-202. (In Polish with English summary.)

HEjNowicz, z. 1959. Eversporting periclinal chimeras. Recent Advances in Botany, 2, $1446-144^{8}$.

IMAI, Y. 1934. On the mutable genes of Pharbitus nil, with special reference to their bearing on the mechanism of bud-variation. 7. Coll. Agric. Tokyo, 12, 479-523.

IMAI, Y. 1935a. Variegated flowers and their derivatives by bud variation. $\mathcal{F}$. Genet., 30, I-13.

IMAI, Y. $1935 b$. The structure of albomarginata and medioalbinata forms. $\mathcal{F}$. Genet., 3I, 53-65.

IMAI, Y. 1936. Geno- and plasmotypes of variegated Pelargoniums. 7. Genet., 33, 169-195.

jones, w. neilson. 1934. Plant Chimeras and Graft Hybrids. Methuen and Co., London.

KÜMMLER, A. 1922. Über die Funktion der Spaltöffnungen weissbunter Blätter. 7b. wiss. Bot., 6r, 61 о-669.

KÜSTER, E. 1919. Über weissrandige Blätter und andere Formen der Buntblättrigkeit. Biol. Zbl., 39, 21 2-251.

MACFARLANE, M. J. 1895 . A comparison of the minute structure of plant hybrids with that of their parents, and its bearing on biological problems. Trans. roy. Soc. Edinb., 37, 203-286.

NOACK, K. L. I922. Entwicklungsmechanische Studien an panaschierten Pelargonien. Zugleich ein Beitrag zur Theorie der Periklinalchimären. $3 b$. wiss. Bot., 6I, 459-534.

RENNER, O. 1936a. Zur Kenntnis der nichtmendelnden Buntheit der Laubblätter. Flora, Jena, 130, 2 18-29o.

RENNER, o. 1936b. Zur Entwicklungsgeschichte randpanaschierter und reingrüne Blätter von Sambuscus, Veronica, Pelargonium, Spirca, Chlorophytum. Flora, Jena, I30, 454-466.

RENNER, O., AND voss, M. 1942. Zur Entwicklungsgeschichte randpanaschierter Formen von Prunus, Pelargonium, Veronica, Dracena. Flora, Jena, 135, 356-376.

Rischkow, v. L. 1927. Die Verbreitung der Chlorophylls und der Peroxydasegehalt der Epidermis buntblättriger Pflanzen. Biol. Zbl., 47, 501-512.

RIschkow, v. L. 1936. Buntblättrigen Chimären und der Ursprung des Mesophylls bei Dicotyledonen. Genetica, $18,313-336$.

SABNIS, T. S. 1923. Inheritance of variegation. Z. Vererbungslehre, 32, 6I-69. 


\section{Plate I}

Fig. I.-Pelargonium zonale var. Mrs G. Clark, GGW. The leaves have a white core (L III) which is masked by the green skin (L II). The white adventitious shoot, developed from the root, confirms the periclinal structure of the variety. $\times \frac{1}{2}$.

Fig. 2.-Pelargonium zonale clone, WGG. This apparently green plant is really a periclinal chimera with a genetically white epidermis (L 1). The structure is confirmed by:(1) Colourless plastids in the guard cells.

(2) Occasional production of pure white sectors on the leaves; three sectors can be seen in the figure.

The clone arose as a bud variation from P.z. var. Flower of Spring, GWG to WGG. $\times \frac{2}{3}$. 

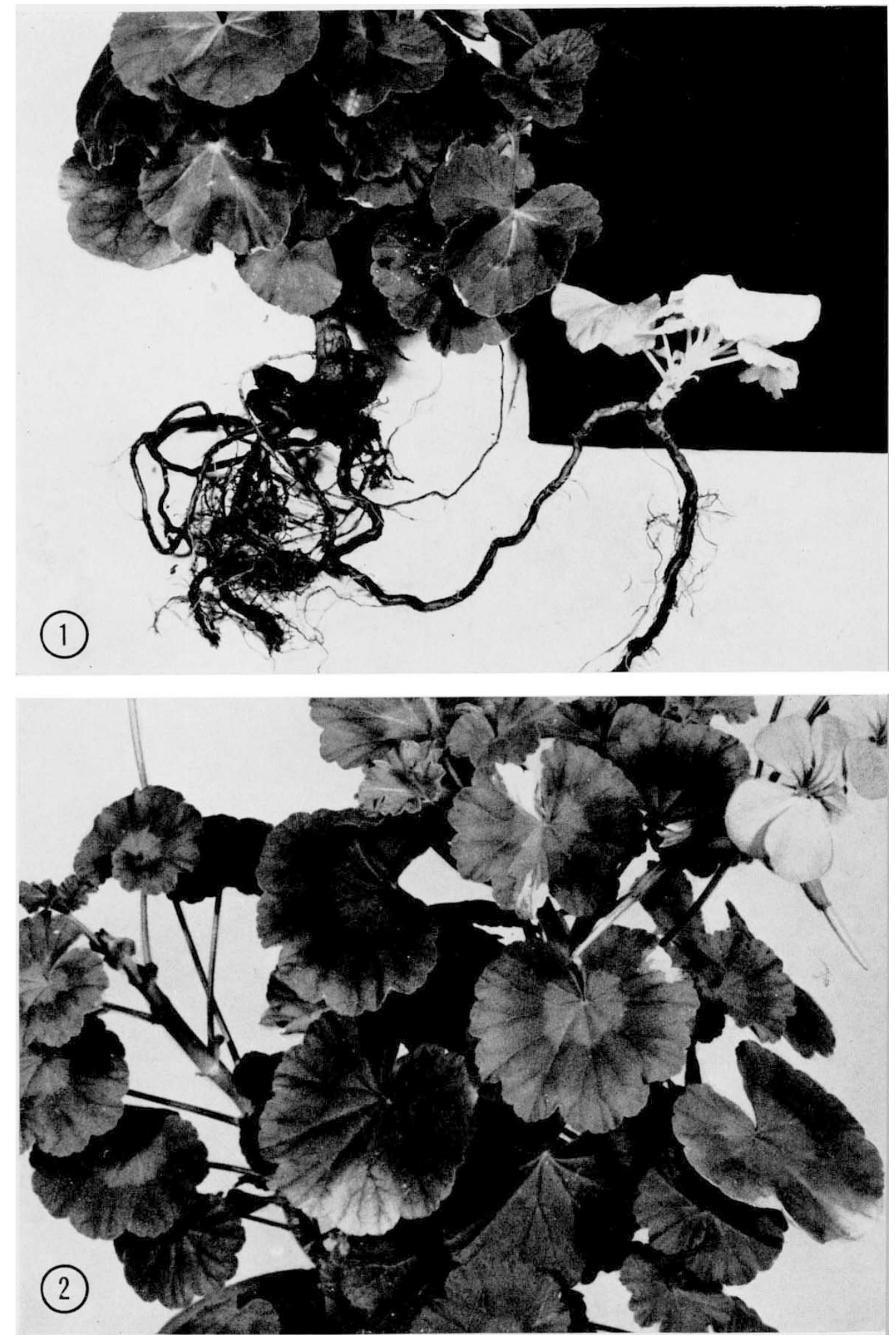


\section{Plate II}

FIG. I.-Spirea (Filipendula) ulmaria variegata, GW or GWW. A G-o-W chimera in which the white core is not masked by the green skin. Assumed by Jones (1934) to be a 3 -layered chimera with the structure GWW. $\times \frac{\text { gin }}{3}$.

FIG. 2.-Hydrangea hortensis variegata, GWG. The green flecks on the margins, especially in the teeth, which are clearly separated from the green core (L III) by white tissue (L II), arise by localised periclinal divisions in the epidermis (L I) during the leaf's development. $\times \mathrm{I}$.

Fig. 3.--Pelargonium elegans var. L'Élégante, GWG. A W-o-G chimera, with an unseen green epidermis, in which periclinal divisions in L I are infrequent during leaf development, so that marginal green flecks are uncommon. Five stages in reversal of GWG to GGW are shown. Reversal, in which the W-o-G chimera appears to turn inside-out to produce a G-o-W chimera, is caused by duplication of $\mathrm{L} I$ in the apex in such a way that layers II and III are displaced inwards. $\times \frac{1}{2}$.

FIG. 4.-Pelargonium zonale var. Freak of Nature, GWW.

Centre: Normal leaf of Freak of Nature with an unmasked white centre and a wide green margin produced by periclinal division in L I during development.

Left: Leaf from an apparently white shoot which is a frequent bud variation. The structure GWW is shown by :-

(1) Green chloroplasts in the guard cells.

(2) Occasional production of pure green flecks on the leaves.

Hence the white leaves are really periclinal chimeras with a genetically green epidermis just as in the variety.

Right: Bud variation, GGW, caused by duplication of L I in the apex (GWW to GGW), in which the white centre (L III) is masked by the overlying green skin (L II). $\times \frac{3}{4}$. 

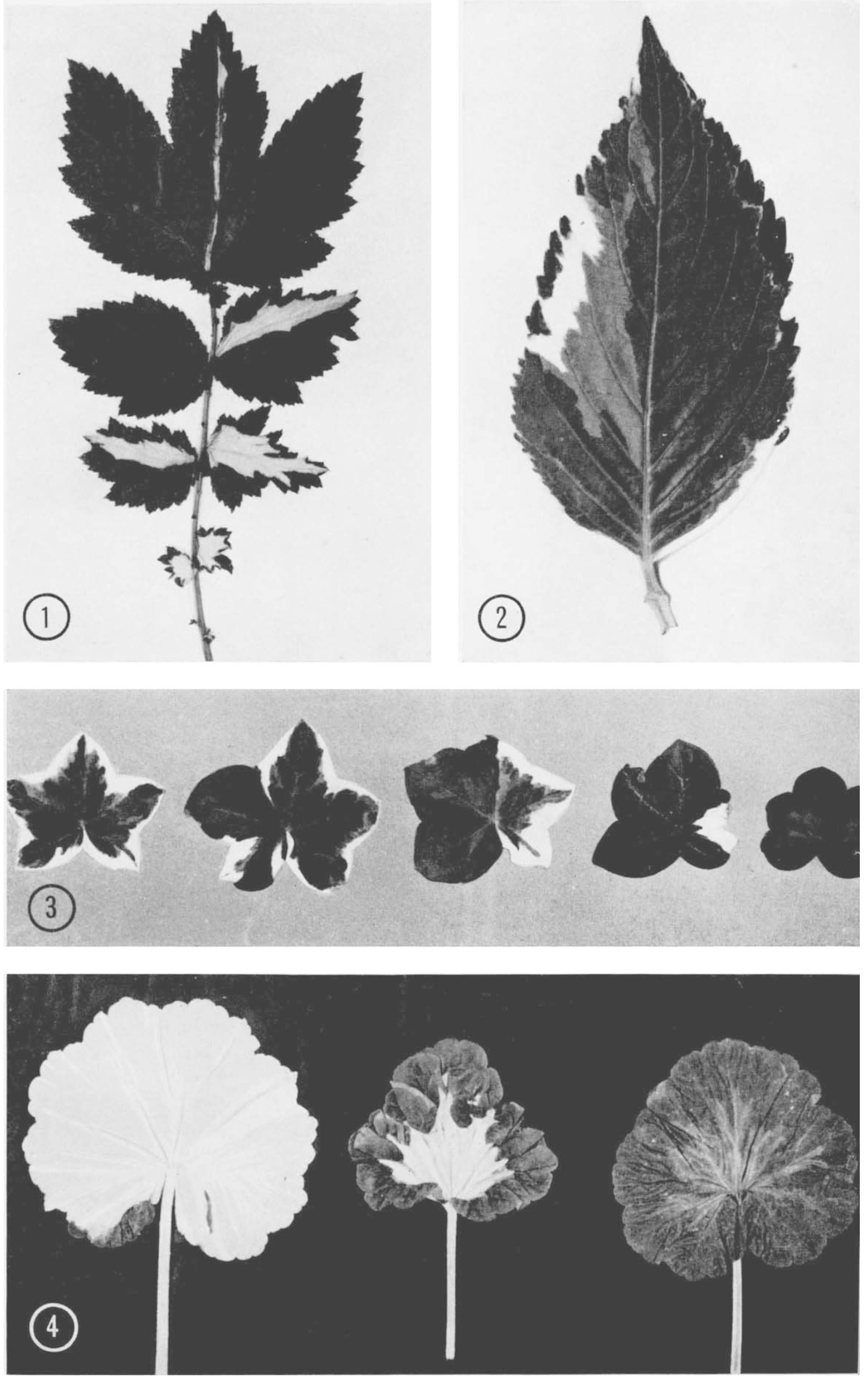


\section{Plate III}

Fig. I.-Funkia (Hosta) sieboldiana albomarginata, WG. A W-o-G Monocotyledon with a 2-layered structure. The white margin is developed from L I and the green centre from L II. $\times \frac{1}{3}$.

FIG. 2.-Veronica gentianoides albocincta, WG. A W-o-G Dicotyledon with a 2-layered structure. The white margin is developed from L I and the green centre from L II $\times I$.

Fig. 3 .

Left: Euonymus japonicus mediopictus, GW, GGW or GWW.

Centre: Eleagnus pungens aureo-variegata, GW, GGW or GWW.

Right: Pelargonium zonale var. A Happy Thought, GGW.

These G-o-W chimeras have an unmasked white centre. Imai (1934 and 1935b) has suggested that this is the result of the bleaching of the overlying green skin by "toxic" substances diffusing from the white core. $\times 1$. 

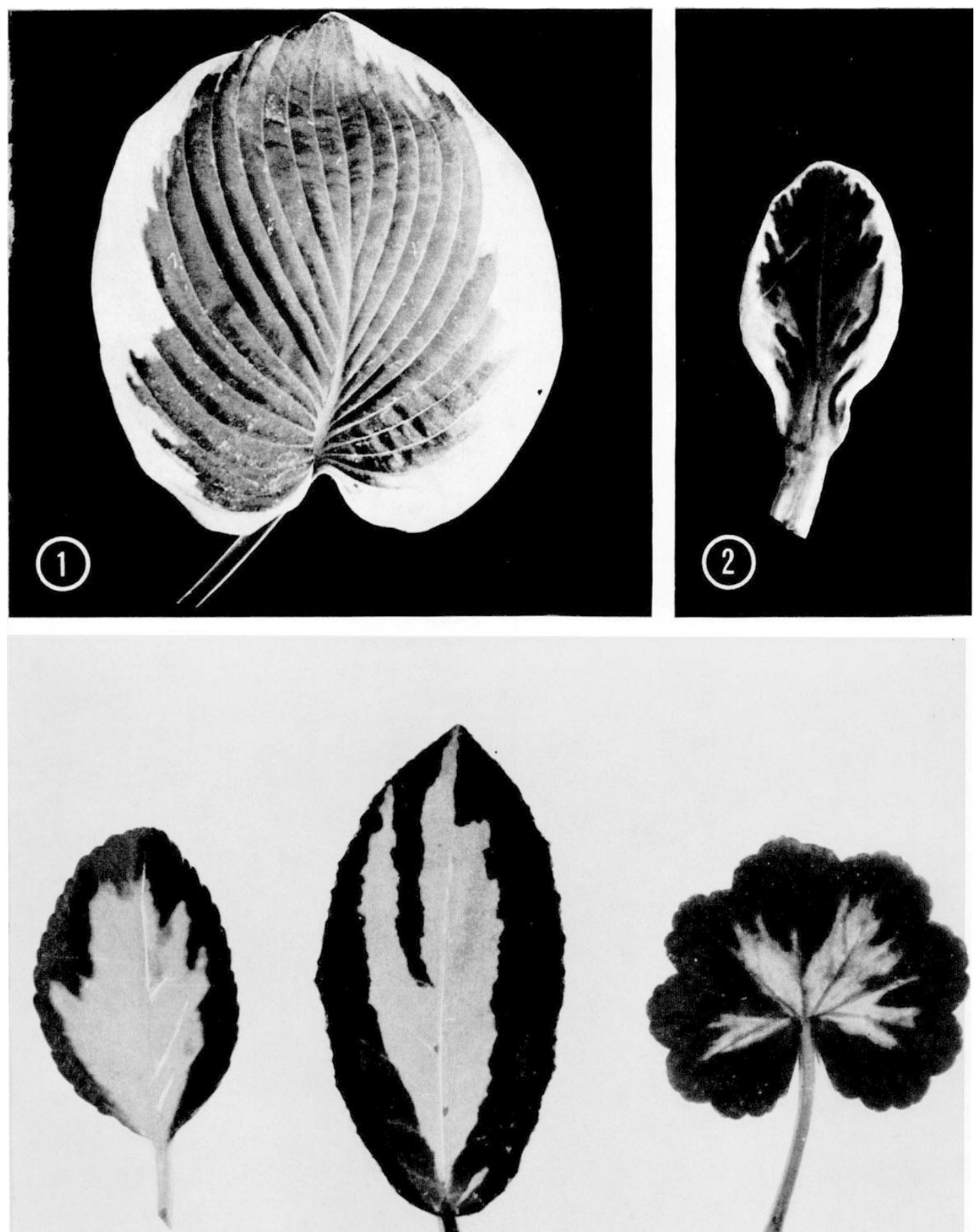

(3)
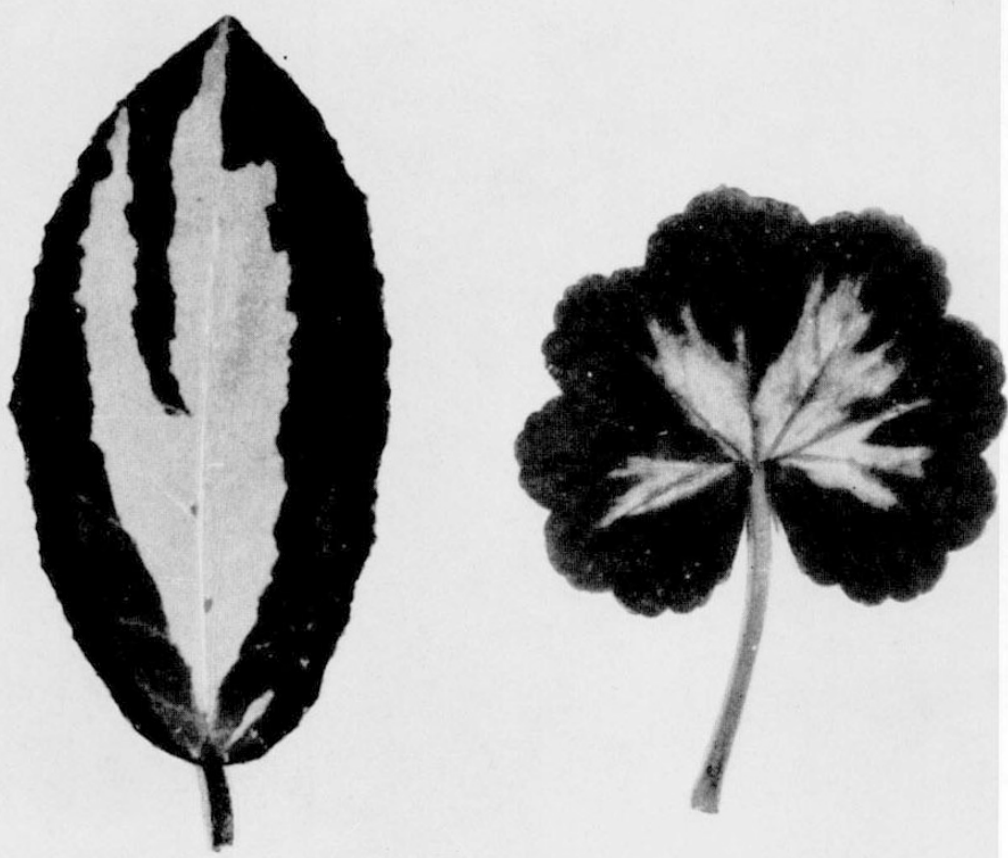


\section{Plate IV}

Fig. I.-Funiperus sabina variegata, WG. An example of a periclinal chimera in a 2-layered Gymnosperm. The apparently green leaves are really periclinal chimeras with a genetically white epidermis (L I). White leaves arise owing to the frequent periclinal divisions which occur in the apex and which displace L II (WG to WW). $\times 1$.

Fig. 2.-Spirea japonica bumalda, WG or WGG. (2- and temporarily 3-layered). This Dicotyledon is an example of a stable, unstable periclinal chimera which is stable in its instability. The apparently green leaves are really periclinal chimeras with a genetically white epidermis ( $\mathrm{L} \mathrm{I}$ ). Owing to frequent periclinal divisions in $\mathrm{L} \mathrm{I}$, the unstable growing point produces :

(I) Pure white shoots (WG to WW).

(2) Temporarily, shoots with white margined leaves (WG to WWG).

The stability of the chimera as a whole is maintained by each year's new shoots which arise from near the base of the hardy, green wood. New shoots cannot arise from the previous year's white shoots since these are not hardy. $\times \frac{3}{4}$. 
(1)
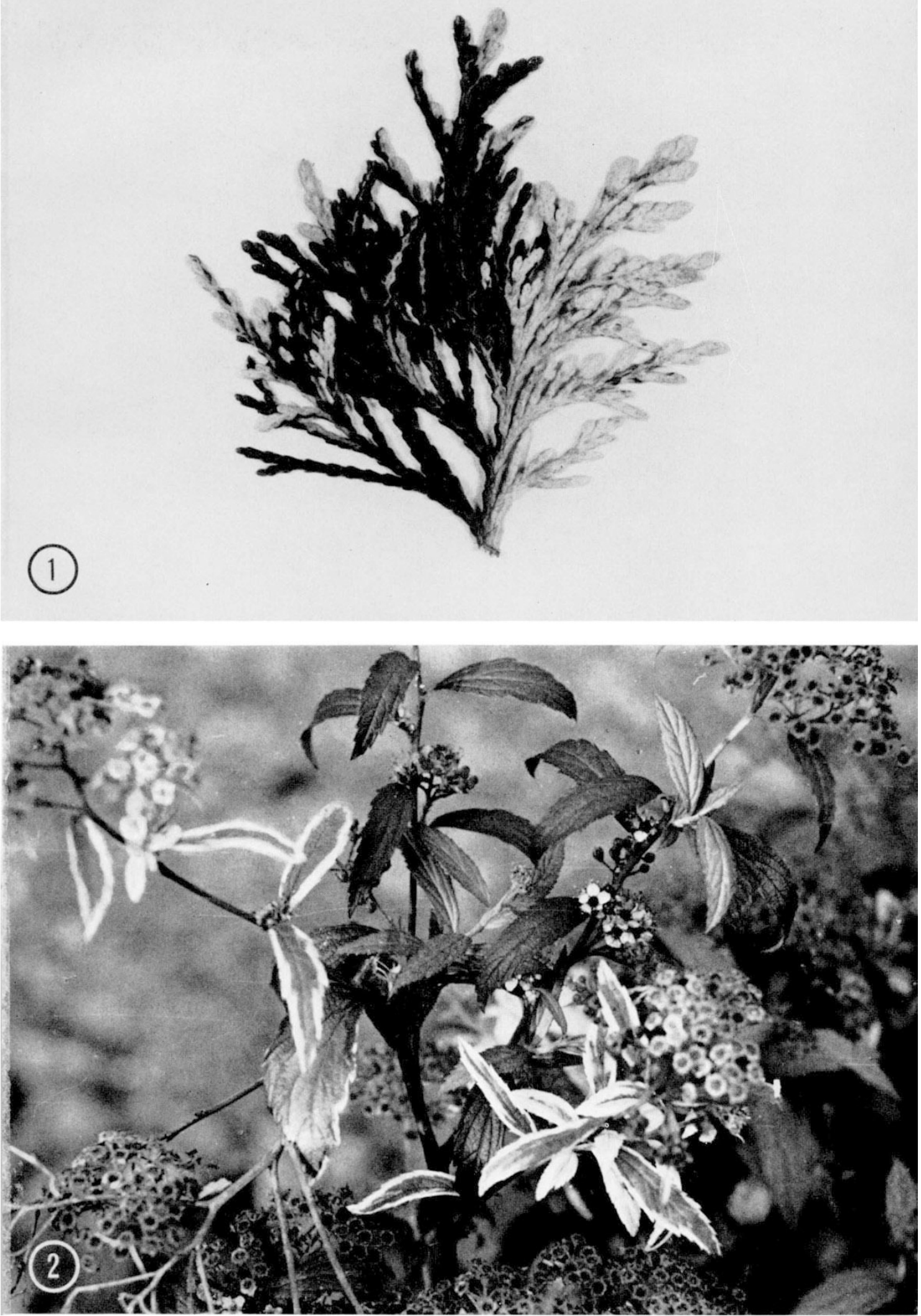
Satina, s., AND Blakeslee, A. F. 1941. Periclinal chimeras in Datura siramonium in relation to development of leaf and flower. Amer. 7. Bot., 28, 862-871.

THIELKE, c. 1948. Beitrage zur Entwicklungsgeschichte und zur physiologie panaschierter Blätter. Planta, 36, 2-33.

THIELKE, C. 1951. Über die Moglichkeiten der Periklinalchimärcnbildung bei Gräsern. Planta, 39, 402-430.

THIELKe, c. 1954. Die histologische Struktur des Sprossvegetationskegels einiger Commelinaceen unter Berücksichtigung panaschierter Formen. Planta, 44, 18-74.

WINKLER, H. 1907. Über Pfropfbastarde und pflanzliche Chimären. Ber. dtsch. bot. Ges., 25, 568-576.

winkler, H. 1910. Über des Wesen der Pfropfbastarde. Ber. disch. bot. Ges., 28, II6-I I8.

winkler, H. 1935. Chimären und Burdonen. Die Lösung des Pfropfbastardproblems. Biologe, 9, 279-290.

YASUI, K. 1929. Studies on the maternal influence of plastid characters in Hosta japonica albomarginata and its derivatives. Cytologia, Tokyo, I, 192-215. 